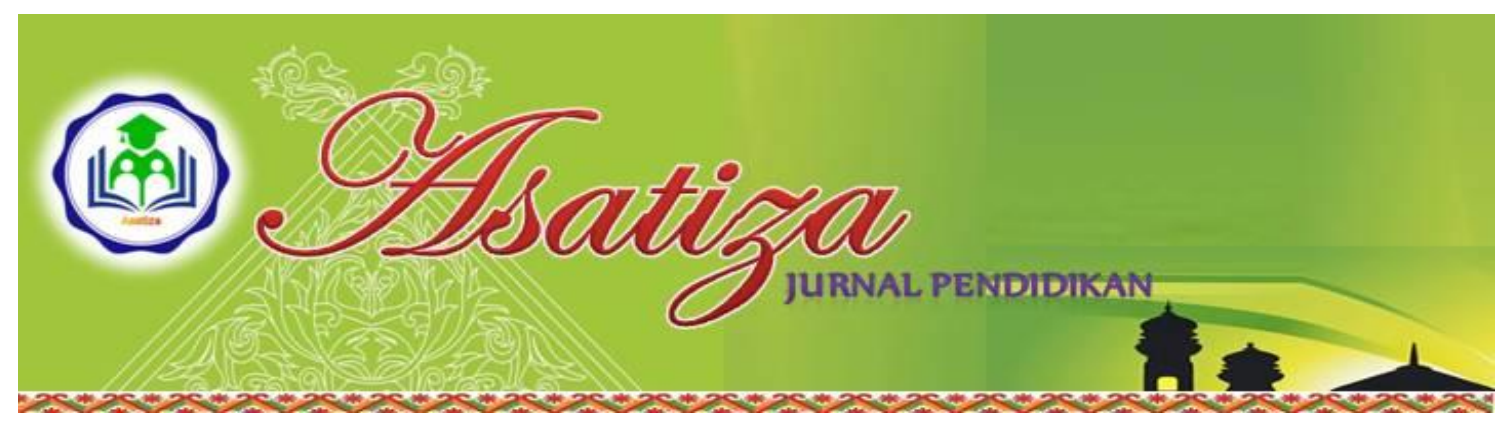

\title{
PERAN GURU DALAM MENANGANI PELANGGARAN DISIPLIN SISWA DI SEKOLAH MENENGAH KEJURUAN NEGERI 02 TEMBILAHAN KOTA
}

\begin{abstract}
Wini $^{1}$
${ }^{1}$ STAI Auliaurrasyidin Tembilahan

Abstrak

Tujuan penelitian ini adalah untuk mengetahui bagaimana peran guru dalam menangani pelanggaran kedisiplinan siswa di Sekolah Menengah Kejuruan (SMK) Negeri 02 Tembilahan Kota, dan Apa yang harus dilakukan guru dalam menangani pelanggaran kedisiplinan siswa.

Subjek dalam penelitian ini adalah guru waka kesiswaan dan guru bimbingan konseling (BK) di SMKN 02 Tembilahan Kota yang berjumlah 13 orang, dan yang menjadi objek dalam penelitian ini adalah peran guru dalam menangani pelanggaran kedisiplinan siswa di SMKN 02 Tembilahan Kota. Untuk mendapatkan data dalam penelitian ini penulis menggunakan teknik pengumpulan data berupa observasi, wawancara dan dokumentasi. Sedangkan teknik analisa data yang penulis gunakan dalam penelitian ini adalah deskriftif kualitatif.

Hasil penelitian menunjukkan peran guru dalam menangani kedisiplinan siswa di SMKN 02 Tembilahan Kota, dapat penulis simpulkan "baik" dengan persentase $72,43 \%$ interval berkisar antara 61\%-80\%. Adapun usaha yang dilakukan guru dalam menangani pelanggaran disiplin siswa yaitumenumbuhkan kesadaran dan pemahaman siswa tentang disiplin, memberikan bimbingan atau penyuluhan, dan Guru dan siswa harus bekerjasama dalam menegakkan kedisiplinan sekolah.
\end{abstract}

Kata Kunci: Peran Guru, Menangani Pelanggaran, Disiplin siswa

\section{A. PENDAHULUAN}

\section{Latar belakang}

Pendidikan sering diartikan sebagai usaha manusia untuk membina kepribadiannya sesuai dengan nilai-nilai dalam masyarakat dan kebudayaan. Dengan berkembangnya, istilah pendidikan atau paedagogik berarti bimbingan atau pertolongan yang diberikan dengan sengaja oleh orang dewasa agar menjadi dewasa. Selanjutnya, pendidikan diartikan sebagai usaha yang dijalankan oleh seseorang atau kelompok orang lain agar menjadi dewasa atau mencapai tingkat hidup atau penghidupan yang lebih tinggi dalam arti mental. ${ }^{1}$

Dalam proses pendidikan tentu adanya seorang guru yang mengajar

${ }^{1}$ Hasbullah, Dasar-Dasar Ilmu Pendidikan, (Jakarta: Raja Grafindo Persada, 2008), hlm. 1. 
dan memberikan sebuah bimbingan kepada peserta didik. Guru adalah tenaga pendidik yang memberikan sejumlah ilmu pengetahuan pada anak didik disekolah ${ }^{2}$ Guru menuntut kepada siswa agar dapat mematuhi kedisiplinan yang telah diterapkan oleh sebuah sekolah, tetapi dibalik itu guru sebagai pendidik dan pengajar juga dituntut agar dapat disiplin dalam menjalankan peran dan tugasnya. Proses pendidikan itu akan berjalan lancar dan nyaman jika komponen yang ada di dalamnya dapat melakukan tugasnya masing-masing secara tertib dan sesuai dengan peraturan.

Guru sebagai pusat proses pendidikan memegang peranan penting dalam menerapkan kedisiplinan agar tidak terjadi pelanggaran kedisiplinan yang akan merugikan segala aspek.

Usia sekolah yang merupakan usia dimana anak akan memperoleh pengalaman luar dan mereka harus beradaptasi sebisa mungkin dengan norma dan peraturan yang berlaku dimana mereka berinteraksi. Banyak aspek kedisiplinan yang sengaja dibuat dan diterapkan disebuah lembaga pendidikan guna menjaga peserta didik tetap berada di koridor yang benar menurut peraturan dan norma, contohnya saja kedisiplinan dalam berpakaian, kedisiplinan waktu, kedisiplinan kebersihan dan lain-lain. Tetapi dalam realitanya menerapkan kedisiplinan itu bukanlah suatu hal yang mudah dan melanggar disiplin itu merupakan hal yang gampang. ${ }^{3}$

Dalam menerapkan kedisiplinan itu perlunya peran seorang guru yang mengarahkan menuju kebaikkan serta memberikan sebuah motivasi kepada peserta didik agar menaati peraturan dan tidak akan melanggarnya. Karena kedisiplinan adalah sebuah kunci keberhasilan seseorang siswa.

Dari observasi yang penulis lakukan sebanyak dua kali dilapangan penulis menemukan kesenjangankesenjangan yang terjadi bahwa guru kurang melakukan pendekatan secara individu dan emosional kepada peserta didik yang bermasalah baik di dalam sekolah maupun di luar sekolah, guru kurang berperan dalam menangani pelanggaran siswa yang datang terlambatan kesekolah, sehingga masih terjadi pelanggaran disiplin serta kurangnya kepatuhan siswa dalam mematuhi segala peraturan yang telah dibuat oleh pihak sekolah. Selain itu ditemukan juga kurang berperannya guru menerapkan peraturan yang dibuat oleh sekolah, menurut penulis masalah ini sangat aktual, dan sangat baik untuk diteliti serta mendapatkan solusi yang baik bagi sekolah. Dalam penelitian ini rumusan masalahnya adalah Bagaimana peran guru dalam menangani pelanggaran disiplin siswa di Sekolah Menengah Kejuruan (SMK) Negeri 02 Tembilahan Kota? dan Apa usaha yang harus dilakukan

${ }^{3}$ Ibid., hlm.4.
${ }^{2}$ Pupuh Fathurrohman dan M. Sobry Suntikno, Strategi Belajar Mengajar, (Bandung: PT. Rafika Aditama, 2010), hlm.43. 
guru dalam menangani pelanggaran disiplin tersebut?

\section{Pengertian Guru di Sekolah}

Istilah guru biasa juga disebut sebagai pendidik, yang artinya orang yang memelihara, merawat dan memberi latihan agar seseorang memiliki pengetahuan. ${ }^{4}$ Menurut Sudarwan Danim dan Khairil:

"Guru bermakna sebagai pendidik professional dengan tugas utama mendidik, mengajar, membimbing, mengarahkan, melatih, menilai, dan mengevaluasi peserta didik pada jalur pendidikan formal ${ }^{5}$

Sedangkan dalam pendapat lain guru (ialah orang dewasa yang karena jabatannya secara formal) selalu mengusahakan terciptanya situasi yang tepat (mengajar) sehingga memungkinkan terjadinya proses pengalaman belajar (learning experiences) pada diri siswa, dengan mengerahkan segala sumber (learning resources) dan menggunakan strategi belajar mengajar (teaching-learning strategy) yang tepat (appropriate). ${ }^{6}$

Menurut Zakiyah Daradjat "Guru adalah pendidik professional, karena secara implisit guru telah merelakan dirinya menerima dan memikul sebagian tanggung jawab pendidikan yang terpikul di pundak para orang tua". ${ }^{7}$

Jadi dari banyaknya paparan tentang guru di atas dapatlah secara umum penulis simpulkan bahwa guru

\footnotetext{
${ }^{4}$ Imam Wahyudi, Mengejar Profesionalisme Guru, (Jakarta: Prestasi Pustaka. 2012), hlm. 44.

${ }^{5}$ Sudarwan Danim dan Khairil, Proofesi Kependidikan, (Bandung: Alfabeta, 2010). hlm. 5.

${ }^{6}$ Abin Syamsudin Makmun, Psikologi Kependidikan, (Bandung: PT Rosdakarya, 2012), hlm. 155.
}

adalah seseorang pendidik atau orang dewasa yang pekerjaannya mengajar atau membimbing peserta didik ke arah yang baik, atau mendewasakan peserta didik ke tingkat dewasa lagi dengan menggunakan berbagai strategi atau cara.

\section{Syarat-Syarat Menjadi Guru}

Adapun syarat-syarat menjadi seorang guru sebagai berikut:

a. Harus memiliki bakat sebagai guru

b. Harus memilki keahlian sebagai guru

c. Memilki kepribadian yang baik dan terintegrasi

d. Memiliki mental yang sehat

e. Berbadan sehat

f. Memiliki pengalaman dan pengetahuan yang luas

g. Berjiwa pancasila

h. Warga Negara yang baik. ${ }^{8}$

S. Nasution yaitu filsafat pendidikan Islam juga menyebutkan 3 bagian tugas guru yaitu:

a. Sebagai orang yang mengkomunikasikan pengetahuan

b. Guru sebagai model, yaitu dalam bidang studi yang diajarkannya merupakan sesuatu yang berguna dan dipraktekan dalam kehidupannya sehari-hari, sehingga guru tersebut menjadi model atau contoh nyata yang

${ }^{7}$ Muhammad Nurdin, Kiat Menjadi Guru Profesional, (Jogyakarta: Ar-Ruzz Media Group, 2010), hlm, 127.

${ }^{8}$ Oemar Hamalik, Proses Belajar Mengajar, (Jakarta: Bumi Aksara, 2011), hlm, 118. 
dikehendaki oleh mata pelajaran tersebut.

c. Guru juga menjadi model sebagai pribadi, apakah berdisiplin, cermat berfikir, mencintai pelajarannya atau yang mematikan idealisme dan picik dalam pandangannya.

Dari ketiga fungsi guru tersebut tergambar bahwa seorang pendidik selain seorang yang memiliki pengetahuan yang akan diajarkannya, juga sebagai seorang berkepribadian baik, berpandangan luas dan berjiwa besar. ${ }^{9}$

Diketahui bahwa guru merupakan Key Person dalam kelas, guru yang memimpin dan mengarahkan pembelajaran. Didepan mata anakanak, guru adalah seorang yang memiliki otoritas, bukan saja otoritas dalam bidang akademis, melainkan jugadalam non akademis, dalam masyarakat guru di pandang sebagai orang yang harus digugu dan ditiru (dituruti dan ditiru), Pengaruh guru terhadap siswa sangat besar.

Guru dewasa ini berkembang sesuai dengan fungsinya, membina sesuai dengan tujuan pendidikan. Lebih-lebih dalam sistem sekolah yang sekarang ini, masalah pengetahuan, kecakapan dan keterampilan tenaga pengajar mendapat perhatian yang serius. Bagaimanapun baiknya kurikulum dan fasilitas perlengkapan, kalau tidak diimbangi dengan peningkatan kualitas guru-gurunya tidak akan mendapatkan hasil yang diharapkan.

\section{Peran Guru Di Sekolah.}

Ada beberapa peran guru yang harus diketahui yaitu sebagai berikut:

a. Guru Sebagai Pengajar

Salah satu tugas yang harus dilaksanakan oleh guru disekolah ialah memberikan pelayanan kepada para siswa agar mereka menjadi siswa atau anak didik yang selaras dengan tujuan sekolah itu. Melalui bidang pendidikan, baik sosial, budaya dan ekonomi.

b. Guru sebagai pembimbing

Bimbingan adalah proses pemberian bantuan terhadap individu untuk mencapai pemahaman dan pengarahan diri yang dibutuhkan untuk melakukan penyesuaian diri secara maksimum terhadap sekolah, keluarga dan masyarakat. ${ }^{10}$

Beberapa peran guru yang diungkapkan oleh Didi Supriadie dan Deni Darmawan yaitu:

1) Sebagai fasilitator Guru berperan sebagai sosok yang memberikan kemudahan bagi peserta didik dalam melakukan proses belajar mengajar.

2) Sebagai motivator

Guru berperan sebagai sosok yang terus memberikan dukungan, sehingga peserta didik secara konsisten memiliki energi, minat, hasratdan keinginan untuk melakukan kegiatan belajar. 
3) Sebagai pemacu

Guru berperan sebagai sosok yang terus memberikan dorongan, rangsangan, menyemangati peserta didik, dan memberikan atmosfer pembelajaran secara kondusif sehingga peserta didik terpacu untuk melakukan kegiatan belajar.

4) Sebagai perekayasa pembelajaran Guru berperan sebagai sosok analis, pengambil keputusan, perencana, pelaksana, manajer leader, organisator, dan evaluator pembelajaran.

5) Sebagai inspiratory pembelajaran Guru berperan sebagai sosok "raw model" teladan yang patut digugu dan ditiru, dan sebagai orang yang selalu memberikan inspirasi, penggagas dalam proses belajar. ${ }^{11}$ Guru harus dapat menempatkan diri dan menciptakan suasana yang kondusif, karena fungsi guru di sekolah sebagai "Bapak" kedua yang bertanggung jawab atas pertumbuhan dan perkembangan jiwa anak. $\mathrm{KH}$ Hajar Dewantara telah menggariskan pentingnya peranan guru dalam proses pendidikan dengan ungkapan:

a. Ing ngarsa sung tulada berarti di depan memberiteladan asas ini sesuai prinsip modeling yaitu keteladan dan contoh bagi muridmuridnya.

b. Ing madya mangun karsa berarti di tengah menciptakan peluang

${ }^{11}$ Didi Supriadie dan Deni Darmawan, Komunikasi Pembelajaran, (Bandung: PT Remaja Rosdakarya, 2012), hlm, 84.

${ }^{12}$ Abdul Majid, Prencanaan pembelajaran, (Jakarta: Rosda Karya,2006), hlm. 47. berprakarsa. Yaitu guru mendorong siswa unutk menghasilkan sebuah karya dan mencapai hasil belajar.

c. Tut wuri handayani Berarti dari belakang memberikan dorongan dan arahan kepada siswa-siswanya. Mereka juga berperan sebagai pengarah atau pembimbing dan tidak akan membiarkan siswanya melakukan hal yang melanggar peraturan. $^{12}$

Dari uraian di atas dapat dilihat bahwa semua peran guru sangat berkesinambungan dan sekaligus merupakan suatu keterpaduan dalam pendidikan disekolah.

\section{Pengertian Disiplin.}

a. Disiplin Sekolah

Sekolah adalah suatu lembaga sosial yang berfungsi memenuhi atau memuaskan kebutuhankebutuhan peserta didik dalam hal pendidikannya. Kepatuhanan peserta didik itulah dinamakan kedisiplinan. Disiplin berasal dari kata latin yaitu disciplina dan discpulus yang berarti perintah dan peserta didik. Jadi disiplin dapat dikatakan sebagai perintah seorang guru kepada peserta didiknya. ${ }^{13}$ Kamus bahasa Indonesia disiplin dapat diartikan latihan batin atau

${ }^{13}$ Novan Ardy Wiyani, Manajemen KelasTeori dan Aplikasi Untuk Menciftakan Kelas Yang Kondusif, (Jogjakarta: Ar-Ruzz Media, 2013), hlm. 159. 
watak supaya menaati tata tertib atau kepatuhan pada aturan. ${ }^{14}$

Sementara itu Liang Gie yang dikutip oleh Novan Ardy Wiyani mengatakan disiplin sebagai suatu keadaan tertib yang mana orangorang yang bergabung dalam suatu organisasi tunduk pada peraturanperaturan yang telah ada dengan senang hati. ${ }^{15}$

Dari banyaknya paparan di atas mengenai kedisiplin sekolah dapat penulis simpulkan kedisiplin merupakan suatu keadaan tata tertib yang harus dipatuhi oleh setiap individu. Jika dikaitkan disekolah maka kedisiplin merupakan suatu atauran yang dibuat oleh sekolah atau tata tertib yang harus dipatuhi oleh peserta didik disekolah.

Dalam rangka menyukseskan pendidikan disekolah, guru harus mampu menumbuhkan disiplin peserta didik, terutama disiplin diri (Self discipline), guru harus mampu membantu peserta didik mengembangkan pola perilakunya, meningkatkan standar perilakunya, dan melaksanakan aturan sebagai alat untuk menegakkan disiplin ${ }^{16}$ Untuk menegakkan kedisiplinan tidaklah mudah bagi seorang guru disekolah dan tidak hanya cukup dengan kata-kata saja, bagi guru untuk menegakkan kedisiplinan perlu proses yang cukup panjang dan memerlukkan bentuk kesabaran.

${ }^{14}$ Aprilia Kumala dan F, Arundaya, Kamus Bahasa Indonesia, (Surabaya: Ikhtiar, 2010), hlm. 117.

${ }^{15}$ Ibid., hlm. 159.
Sekolah sebagai lembaga pendidikan berfungsi dan bertujuan untuk mengembangkan potensi manusia, baik dalam peningkatan pengetahuan umum, maupun peningkatan pendidikan keimanan dan ketaqwaan, hal itu menjadi tugas utama sekolah, bukan hanya tanggung jawab guru agama atau PPKN akan tetapi juga tugas seluruh warga sekolah. ${ }^{17}$

Ada beberapa tata tertib yang penulis lampirkan sebagai suatu penelian di Sekolah Menengah Kejuruan (SMK) Negeri 02 Tembilahan Kota yaitu sebagai berikut:

\begin{tabular}{|c|l|l|}
\hline NO & \multicolumn{1}{|c|}{ TATA TERTIB } & JABATAN \\
\hline 1. & $\begin{array}{l}\text { RAMBUT } \\
\text { a. Rambut panjang } \\
\text { b. Rambut di cat } \\
\text { c. Rambut digarisi }\end{array}$ & $\begin{array}{l}\text { Guru/piket } \\
\text { /walas/BP }\end{array}$ \\
\hline 2. & $\begin{array}{l}\text { KUKU } \\
\text { a. Kuku dicat } \\
\text { b. Kuku panjang }\end{array}$ & $\begin{array}{l}\text { Guru/piket } \\
\text { /walas/BP }\end{array}$ \\
\hline 3. & $\begin{array}{l}\text { Membawa aksesoris } \\
\text { yang berlebihan } \\
\text { disekolah }\end{array}$ & $\begin{array}{l}\text { Guru/piket } \\
\text { /walas/BP }\end{array}$ \\
\hline 4. & $\begin{array}{l}\text { HANDPHONE } \\
\text { a. Mengaktifkan HP } \\
\text { yang mengganggu } \\
\text { kegiatan PBM. } \\
\text { Membawa Hp yang } \\
\text { berisi kata-kata } \\
\text { kotor, menghasut, } \\
\text { propokator dll. } \\
\text { Membawa dan } \\
\text { mengaktifkan video } \\
\text { porno }\end{array}$ & /walas/BP \\
\hline $\begin{array}{l}\text { Terlambat dalam } \\
\text { mengikuti PBM. } \\
\text { a. Terlambat } \\
\text { menit }\end{array}$ & 1-10 \\
\hline
\end{tabular}

${ }^{16}$ E. Mulyasa, Manajemen Pendidikan Karakter, (Jakarta: Bumi Aksara, 2013), hlm. 26.

${ }^{17}$ Eka Prihatin, Manajemen Peserta Didik, (Bandung: Alfabeta, 2011), hlm. 89. 


\begin{tabular}{|c|c|c|}
\hline & $\begin{array}{l}\text { b. Terlamabat 11-20 } \\
\text { menit } \\
\text { c. Terlambat lebih dari } \\
20 \text { menit } \\
\text { d. Cabut } \\
\text { e. Alfa }\end{array}$ & \\
\hline 6. & $\begin{array}{l}\text { Mengancam teman, guru, } \\
\text { warga sekolah, merusak } \\
\text { sarana sekolah }\end{array}$ & Kesiswaan \\
\hline 7. & 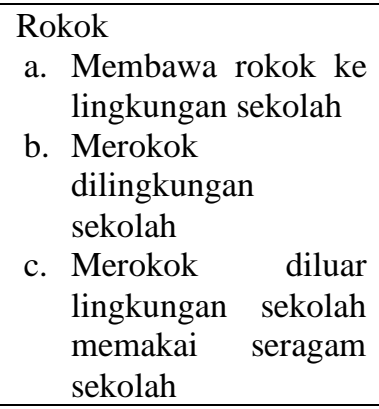 & Kesiswaan \\
\hline 8. & $\begin{array}{l}\text { Membawa, meminum, } \\
\text { minuman keras } \\
\text { dilingkungan sekolah } \\
\text { maupun dimasyarakat }\end{array}$ & Kesiswaan \\
\hline 9. & $\begin{array}{l}\text { Mencuri dilingkungan } \\
\text { sekolah maupun } \\
\text { dimasyarakat }\end{array}$ & Kesiswaan \\
\hline 10. & $\begin{array}{l}\text { Membawa, } \\
\text { menggunakan senjata } \\
\text { tajam untuk membuat } \\
\text { tindakan kejahatan } \\
\text { disekolah }\end{array}$ & $\begin{array}{l}\text { Walas/BP/ } \\
\text { kesiswaan }\end{array}$ \\
\hline 11. & $\begin{array}{l}\text { Terlibat kegiatan } \\
\text { narkoba yang dibuktikan } \\
\text { dengan } 2 \text { orang } \\
\text { saksi/dijatuhi hukuman }\end{array}$ & $\begin{array}{l}\text { Walas/BP/ } \\
\text { kesiswaan }\end{array}$ \\
\hline 12. & Bertato, tindik (laki-laki) & $\begin{array}{l}\text { Walas/BP/ } \\
\text { Kesiswaan }\end{array}$ \\
\hline 13. & $\begin{array}{l}\text { Melakukan tindakan } \\
\text { asusila di dalam ataupun } \\
\text { diluar lingkungan } \\
\text { sekolah }\end{array}$ & Kesiswaan \\
\hline 14. & $\begin{array}{l}\text { Mengucapkan kata-kata } \\
\text { kotor kepada teman, guru } \\
\text { dan warga sekolah }\end{array}$ & $\begin{array}{l}\text { Walas/ } \\
\text { Kajur/BP }\end{array}$ \\
\hline 15 . & $\begin{array}{l}\text { Berkelahi } \\
\text { a. Dilingkungan sekolah } \\
\text { tidak menyebabkan } \\
\text { cidera } \\
\text { b. Dilingkungan sekolah } \\
\text { menyebabkan } \\
\text { cidera } \\
\text { c. Di luar lingkungan } \\
\text { sekolah }\end{array}$ & $\begin{array}{l}\text { Kesiswaan } \\
\text { /KEPSEK }\end{array}$ \\
\hline
\end{tabular}

${ }^{18}$ Waka Bidang Kesiswaan Sekolah Menengah Kejuruan Negeri 02 Tembilahan Kota, Tata Tertib Siswa, (Tembilahan.2013). \begin{tabular}{|c|l|l|}
\hline 16. & Dijatuhi vonis hukuman & KEPSEK
\end{tabular} pengadilan.

Sumber Data: Dokumentasi Sekolah Menengah Kejuruan (SMK) Negeri 02 Tembilahan Kota. $^{18}$

b. Sumber-sumber Pelanggaran disiplin

Pelanggaran disiplin itu sangat unik, bersifat sangat pribadi, kompleks dan kadang-kadang mempunyai latar belakang yang mendalam lain dan sebab-sebab yang tampak walaupun demikian memang ada yang bersifat umum misalnya:

1) Kebosanan dalam kelas merupakan sumber pelanggaran disiplin. siswa tidak tahu apalagi yang harus mereka kerjakan karena yang dikerjakan itu ke itu saja. Harus diusahakan agar peserta didik tetap sibuk dengan kegiatan bervariasi dengan taraf perkembangannya.

2) Perasaan kecewa dan tertekan karena peserta didik dituntut untuk bertingkah laku yang kurang wajar sebagai remaja.

3) Tidak terpenuhinya kebutuhan akan perhatian, pengenalan atau status. ${ }^{19}$

Usia siswa yang berada pada tingkat sekolah menengah atas merupakan anak pada usia remaja. Pada usia remaja inilah sangat rentan terjadi kenakalan remaja dan pelanggaran disiplin tanpa terkecuali di sekolah. Telah banyak usaha untuk mengamati dan merumuskan perubahan-perubahan anak dalam aspek nilai-nilai dan identifikasi sejalan dengan pertumbuhannya yang tampak 
dalam bermacam-macam pola prilaku.

Jansen yang dikutip oleh Oemar Hamalik dalam bukunya psikologi belajar mengajar mengatakan bahwa perlu mengetahui motivasi dan prilaku para pemudaan menggunakan pengetahuan itu untuk membuat perencanaan dan usaha yang akan dilakukan. Jansen mengemukakan sejumlah preposisi yang perlu untuk mengarahkan tindakan guru terhadap para remaja, dan kemudian menyarankan beberapa implikasi bagi guru yaitu sebagai berikut:

a) Motif dasar semua organisme adalah konservasi dan pembagian kesempatan bagi fenomena diri (Self).

b) Keberhasilan diartikan dalam kaitannya dengan tujuantujuan personal, bukan pada ukuran-ukuran yang ditentukan oleh orang lain.

c) Perilaku itu rasional.

d) Remaja bertindak untuk mempertahankan fenomena selfnya.

e) Ruang gerak bebas mempengaruhi prilaku dan penyesuaian diri para remaja.

f) Salah satu masalah pokok yang dihadapi para remajaadalah pelaksanaan tugas - tugas perkembangan bagi kelompoknya.

Proporsi itu hendaknya digunakan sebagai landasan psikologi oleh guru dalam upaya melakukan tindakan-tindakan edukatif terhadap siswanya.

c. Beberapa Kesalahan-kesalahan Seorang Guru di Sekolah.
Ada beberapa kesalahan-kesalahan yang terjadi pada seorang guru, berbicara kesalahan pada guru dalam mendidik para muridnya tentu tidak terbatas pada 10 macam saja. Jika melihat kesalahan itu sangat banyak sama banyaknya kebenaran yang dilakukan oleh para guru. Sebagai buktinya, betapapun banyaknya kesalahan para guru dalam mendidik muridnya, saat ini banyak dilihat para sarjana yang telah lulus berkat bimbingan dan asuhan para guru mulai dari tingkat dasar sampai perguruan tinggi. Dalam bukunya pengelolaan pengajaran Ahmad Rohani menyatakan bahwa:

"Pembiasaan dengan disiplin disekolah akan mempunyai pengaruh ruang positif bagi kehidupan peserta didik dimasa yang akan datang.Pada mulanya memang disiplin dirasakan sebagai suatu aturan yang mengekang kebebasan peserta didik.akan tetapi apabila aturan ini dirasakan sebagai sesuatu yang harus dipatuhi secara sadar dan untuk kebaikan bersama, maka lama kelamaan akan menjadi suatu kebiasaan yang baik menuju kearah disiplin diri sendiri (Self discipline)". ${ }^{20}$

Adapun 10 kesalahan atau kendala para guru dalam mendidik para siswanya:

a. Tidak mencintai profesi guru

Banyak dijumpai di masyarakat dan juga di dunia pendidikan sesorang menjadi guru bukan karena ingin menjadikan guru sebagai profesi, tapi karena terpaksa. Hal itu bisa jadi karena tak dapat diterima pada profesi

${ }^{20}$ Ahmad Rohani, Pengelolaan Pengajaran, (Jakarta: Rineka Cipta, 2004), hlm. 79. 
yang lain alis dari pada menganggur.

b. Tidak siap fisik dan psikis

Banyak dijumpai guru yang tampil di depan kelas pagi hari dengan wajah yang kusam dan merengut. Hal itu bisa jadi karena sang guru karena dibebani segudang masalah ekonomi atau problem lain sehingga menumpuk dipundaknya.

c. Lebih menekankan mengajar ketimbang mendidik

Ada beberapa contoh anak didik pulang kerumahnya tanpa membawa hasil belajarnya dari sekolah. Anak didik merasa sudah belajar tetapi tidak memahami apa yang telah dipelajarinya. Solusinya: Pendidik seharusnya menekankan atau memperbanyak penjelasan, baik mengenai cara belajar ataupun bahasan yang akan diajarkan dan Seorang pendidik harus lebih penyabar, pengayom dan telaten.

d. Mendidik dan mengajarkan tidak sistematis

Dalam menerapkan salah satu konsep didaktik metodik (suruhan, larangan, hadiah dan hukuman) dan tidak profesional. Disatu pihak ada yang malaksanakannya secara indroktinisasi tetapi dipihak lain ada yang melaksanakannya secara bebas (tidak terarah).

e. Pendidik tidak mengenali aspek individu anak

Keberhasilan belajar mengajar tidak hanya ditentukan oleh tingkat kecerdasan tetapi banyak sekali factor pendukung seperti: kesiapan fisik, psikis, semangat, tanggung jawab, dukungan orang tua, pengaruh lingkungan, dan lainnya. Solusinya: Mencari tahu atau menyelidiki apa saja yang menjadi penyebabnya dan melakukan kunjungan secara berkala kerumah anak didik.

f. Menyerahkan anak didik yang bermasalah lansung ke guru Bk.

Banyak sekali penyebabnya anak bermasalah dalam belajar, sehingga mengakibatkan anak didik tidak dapat belajar dengan optimal. Ditelusuri lebih jauh masalahnya dan karena merasa bukan bidangnya, pendidik langsung menyerahkan anak kepada guru BK (bimbingan dan solusinya).

g. Guru kurang memberikan teladan

Karena pengaruh berbagai hal mulai dari pengaruh fisik, psikis, ekonomi, stress, lingkungan dan sebagainya. Disatu sisi guru kurang penyabar, dilain pihak sang anak didik terlalu kreatif bahkan cenderung agresiif.

h. Makanan yang tidak halal

Salah satu dosa para orang tua kepada anak-anaknya adalah memberikan nafkah yang tidak halal kepada anggota keluarganya. Makanan atau minuman serta perlengkapan rumah tangga yang berasal dari uang haram maka besar sekali pengaruhnya terhadap kepribadian seseorang. Imam shadiq berkata: "perolehan barang haram akan tampak pengaruhnya pada anak-anak dan keturunan seseorang".

i. Salah memberikan nama kepada anak. 
Oleh karena itu jangan sampai sembarangan dalam memberikan nama kepada anak dan seorang guru jangan memanggil nama anak dengan sebutan yang tidak baik.

j. Memilih pendidikan anak yang tidak agamis

Pendidikan sejak mengasuh bayi, panti asuhan serta lembaga pendidikan, konsep dasar pendidikan yang harus ditanamkan kepada anak dalam Islam adalah seperti yang dicontohkan Luqman Al-Hakim dalam mendidik anakanaknya. $^{21}$ seperti yang terdapat dalam Surah Luqman (31) Ayat 13 Yang artinya:

"Dan ingatlah ketika luqman berkata kepada anaknya diwaktu ia memberikan pelajaran kepadanya:" wahai anakku, janganlah kamu menyekutukan Allah sesungguhnya menyekutukan Allah itu adalah kezaliman yang besar". ${ }^{22}$

\section{Peran Guru Dalam Menangani Pelanggaran Disiplin Sekolah.}

Untuk mendisiplinkan peserta didik perlu dimulai dengan prinsip yang sesuai dengan tujuan pendidikan nasional yakni sikap demokrasi sehingga peraturan disiplin perlu berpedoman pada hal tersebut yakni peserta didik sedangkan guru tut wuri handayani. $^{23}$

Di lingkungan sekolah seorang guru harus berperan aktif untuk menerapkan kedisiplinan, dimana

\footnotetext{
${ }^{21}$ Awaluddin Tjala, 10 Kesalahan Orang Tua dan Guru dalam Mendidik dan solusinya, (Bogor: Aan-Najah Press, 2004), hlm.30

${ }^{22}$ Departemen Agama RI, Al-qur'an dan terjemahannya, (Bandung: CV. Penerbit J-Art, 2005), hlm.413.
}

peran guru di sekolah sebagai motivator siswa, sebagai pembimbing siswa, sebgai fasilator siswa, dan lainlainnya. $^{24}$ ada beberapa cara atau tehnik yang bisa diterapkan oleh seorang guru dalam menangani disiplin siswa di sekolah yaitu sebagai berikut:

\section{a. Teknik Inner Control}

Teknik ini sangat disarankan untuk digunakan guru-guru dalam membina disiplin peserta didiknya. Teknik ini menumbuhkan kepekaan atau penyadaran akan tata tertib dari pada akhirnya disiplin harus tumbuh dan berkembang dari dalam peserta didik itu sendiri (self discipline).

\section{b. Teknik External Control}

Teknik ini yaitu mengendalikan diri siswa berupa bimbingan dan konseling. Teknik dapat menumbuhkan disiplin cendrung melakukan pengawasan (yang kadang perlu diperketat dan kalau perlu menjatuhkan hukuman terhadap setiap pelangaran).

\section{c. Teknik Cooperative Control}

Teknik cooperative control ini sebuah pembinaan disiplin dengan cara bekerjasama antara guru dan siswa dalam mengendalikan disiplin, dimana guru dan siswa saling mengontrol terhadap pelanggaran disiplin sekolah. ${ }^{25}$

Cara menerapkan kedisiplinan di sekolah antara lain:

${ }^{23}$ E. Mulyasa, Manajemen Pendidikan Karakter, (Jakarta: PT Bumi Aksara, 2013), hlm. 26.

${ }^{24}$ Ibid., hlm. 28.

${ }^{25}$ Eka Prihatin, Manajemen Peserta Didik, (Bandung: Alfabeta, 2011), hlm. 96. 
a. Penyusunan rancangan harus melibatkan guru, staf administrasi, wakil siswa dan wakil orang tua.

b. Rancangan harus sesuai dengan misi dan tujuan sekolag.

c. Rancangan harus singkat dan jelas.

d. Rancangan harus memuat daftar perilaku yang dilarang beserta sansi.

e. Peraturan yang telah disepakati bersama harus di sebarluaskan.

f. Kegiatan yang terkait dengan aktifitas siswa, harus di arahkan dalam pembentukkan disiplin sekolah. ${ }^{26}$

\section{B. METODOLOGI}

Subjek adalah pokok pembicaraan atau pokok pembahasan. ${ }^{27}$ Adapun yang menjadi subjek dalam penelitian ini adalah guru Bimbingan Konseling (BK) dan guru Waka Kesiswaan Sekolah Menengah Kejuruan (SMK) Negeri 02 Tembilahan Kota. Objek adalah hal perkara atau orang yang menjadi pokok pembicaraan. ${ }^{28}$ Adapun objek dalam penelitian ini adalah peran guru dalam menangani Pelanggaran Disiplin di Sekolah Menengah Kejuruan (SMK) Negeri 02 Tembilahan. Dalam penelitian ini yang menjadi populasinya adalah Guru Bimbingan Konseling (BK)yang berjumlah 1 orang dan Guru Waka Kesiswaan berjumlah 1 orang ditambah anggota Waka Kesiswaan 11 orangdi Sekolah Menengah Kejuruan (SMK)Negeri 02 Tembilahan Kota. Sedangkan teknik pengumpulan data yang diperlukan, penulis menggunakan

${ }^{26}$ Ibid, hln. 112 . teknik yaitu: Observasi, wawancara dan dokumentasi. Teknik analisa data dalam penelitian ini adalah teknik deskriptip kuantilitatif.

\section{PEMBAHASAN}

Tujuan penelitian ini adalah untuk mengetahui tentang bagaimana peran guru dalam menangani pelanggaran disiplin yang dilakukan oleh siswa Sekolah Menengah Kejuruan (SMK) Negeri 02 Tembilahan Kota.

Untuk mendapatkan data dalam penelitian ini penulis menggunakan teknik observasi, Observasi dilakukan sebanyak Dua kali. Data disajikan dalam bentuk tabel-tabel observasi setiap tabel mengandung 10 (sepuluh) aspek yang merupakan indikator untuk mengetahui peran guru dalam menangani pelanggaran disiplin siswa di Sekolah Menengah Kejuruan Negeri (SMK) 02 Tembilahan Kota, akan tetapi jumlah item yang di observasi berjumlah 18 item. Selanjunya untuk lebih jelas dapat dilihat pada tabeltabel berikut:

\section{Rekapitulasi Observasi Kedua}

\begin{tabular}{|c|l|c|c|c|c|}
\hline \multirow{2}{*}{ NO } & \multirow{2}{*}{$\begin{array}{l}\text { Aspek Yang di } \\
\text { Teliti }\end{array}$} & \multicolumn{4}{|c|}{ Option Jawaban } \\
\cline { 3 - 6 } & YA & & TIDAK & \\
\cline { 2 - 6 } & F & $(\%)$ & F & $(\%)$ \\
\hline \multirow{2}{*}{$\begin{array}{l}\text { Guru menindak } \\
\text { siswa yang } \\
\text { berambut tidak } \\
\text { rapi: }\end{array}$} & & & & \\
\cline { 2 - 6 } & a. Panjang & 11 & 84,61 & 2 & 15,39 \\
\cline { 2 - 6 } & b. Di cat & 13 & 100 & 0 & 0 \\
\cline { 2 - 6 } & c. Di garis & 6 & 46,16 & 7 & 53,84 \\
\hline \multirow{2}{*}{2} & $\begin{array}{l}\text { Guru melarang } \\
\text { siswa mencat: }\end{array}$ & & & & \\
\hline
\end{tabular}

\footnotetext{
${ }^{27}$ Aprilia Kumala, Kamus Bahasa Indonesia, (Surabaya: Ikhtiar, 2011), hlm. 452.

${ }^{28}$ Ibid., hlm. 297.
} 


\begin{tabular}{|c|c|c|c|c|c|}
\hline & a. Kuku & 9 & 69,23 & 4 & 30,77 \\
\hline & $\begin{array}{l}\text { b. Berkuku } \\
\text { panjang }\end{array}$ & 8 & 61,53 & 5 & 38,47 \\
\hline \multirow{3}{*}{3} & $\begin{array}{l}\text { Guru melarang } \\
\text { siswa memakai } \\
\text { aksesoris yang } \\
\text { berlebihan: }\end{array}$ & & & & \\
\hline & $\begin{array}{l}\text { a. Siswa laki-laki } \\
\text { (kalung, cincin, } \\
\text { anting-anting) }\end{array}$ & 6 & 46,16 & 7 & 53,84 \\
\hline & $\begin{array}{l}\text { b. Siswa } \\
\text { perempuan (rok } \\
\text { mini/rok di atas } \\
\text { lutut) }\end{array}$ & 13 & 100 & 0 & 0 \\
\hline 4 & $\begin{array}{l}\text { Guru menindak } \\
\text { siswa yang } \\
\text { mengaktifkan } \\
\text { handphone pada } \\
\text { proses belajar } \\
\text { mengajar. }\end{array}$ & 11 & 84,61 & 2 & 15,39 \\
\hline 5 & $\begin{array}{l}\text { Guru menindak } \\
\text { siswa yang } \\
\text { datang terlambat } \\
\text { dalam mengikuti } \\
\text { proses belajar } \\
\text { mengajar. }\end{array}$ & 5 & 38,47 & 8 & 61,53 \\
\hline & $\begin{array}{l}\text { Guru menindak } \\
\text { siswa yang } \\
\text { mengancam: }\end{array}$ & & & & \\
\hline 6 & a. Guru & 12 & 92,31 & 1 & 7,69 \\
\hline & b. Teman & 12 & 92,31 & 1 & 7,69 \\
\hline & c. Merusak sarana & 9 & 69,33 & 4 & 30,77 \\
\hline 6 & d. prasarana & 12 & 92,31 & 1 & 7,69 \\
\hline 7 & $\begin{array}{l}\text { Guru } \\
\text { menghukum } \\
\text { siswa merokok di } \\
\text { lingkungan } \\
\text { sekolah }\end{array}$ & 13 & 100 & 0 & 0 \\
\hline 8 & $\begin{array}{l}\text { Guru melarang } \\
\text { siswa } \\
\text { bertato(bertindik) } \\
\text { terutama siswa } \\
\text { laki-laki }\end{array}$ & 13 & 100 & 0 & 0 \\
\hline 9 & $\begin{array}{l}\text { Guru menindak } \\
\text { siswa yang } \\
\text { terlibat } \\
\text { perkelahian di } \\
\text { luar maupun di } \\
\text { dalam lingkungan } \\
\text { sekolah. }\end{array}$ & 12 & 92,31 & 1 & 7,69 \\
\hline 10 & $\begin{array}{l}\text { Guru menindak } \\
\text { siswa yang } \\
\text { terlibat: }\end{array}$ & & & & \\
\hline
\end{tabular}

${ }^{29}$ Amirul Hadi dan Hayono, Metodologi Penelitian Pendidikan, (Bandung: CV Pustaka Setia, 2005), hlm. 45.

\begin{tabular}{|l|l|r|r|c|c|}
\hline & a. Narkoba & 4 & 30,77 & 9 & 69,23 \\
\hline b. Minuman keras & 7 & 53,84 & 6 & 46,16 \\
\hline & JUMLAH & 176 & 75,21 & 58 & 24,79 \\
\hline
\end{tabular}

Dari tabel rekapitulasi hasil observasi keduadi atas, dapat kita lihatbahwa jawaban "Ya" berjumlah 176, sedangkan jawaban "Tidak" berjumlah 58 dari 18 aspek yang diteliti mengenai peran guru dalam menangani pelanggaran disiplin siswa di Sekolah Menengah Kejuruan (SMK) Negeri 02 Tembilahan Kota. Sedangkan langkah menghitungannya hal ini dapat dicari dengan rumus:

$$
\mathrm{P}=\frac{F}{N} \mathrm{X} 100 \%
$$

Untuk menentukan nilai $\mathrm{F}$ dengan cara memberikan bobot pada jawaban hasil observasi. Untuk jawaban "Ya" dengan bobot (1) sedangkan jawaban "Tidak" dengan bobot (0). ${ }^{29}$

Untuk menentukan $\mathrm{F}$ dengan cara:

a. Nilai Ya: 176 X $1=176$

b. Nilai Tidak: $58 \times 0=0$

Sedangkan untuk menentukan nilai $\mathrm{N}$ dengan cara sebagai berikut:

$\mathrm{N}=$ item observasi $\mathrm{X}$ Jumlah Observasi X Responden X Skor tertinggi

$$
\mathrm{N}=18 \mathrm{X} 1 \mathrm{X} 13 \mathrm{X} 1
$$

$\mathrm{N}=234$

$$
\begin{aligned}
\text { Maka: } \mathrm{P} & =\frac{F}{N} \mathrm{X} 100 \% \\
\mathrm{P} & =\frac{176}{234} \mathrm{X} 100 \% \\
\mathrm{P} & =75,21 \%
\end{aligned}
$$

Berdasarkan rekapitulasi hasil observasi kedua penulis kepada waka kesiswaan dan guru bimbingan konseling (BK) tersebut mengenai peran guru dalam 
menangani pelanggaran disiplin siswa di Sekolah Menengah Kejuruan (SMK) Negeri 02 Tembilahan Kota adalah "Sangat Baik" dengan persentase 75,21\% interval berkisar antara 61\%-80\%.

\section{Penyajian Hasil Wawancara}

Dalam penelitian ini penulis juga menggunakan teknik pengumpulan data berupa wawancara sebagai penunjang penelitian ini. Wawancara dilakukan untuk mempertanyakan beberapa pertanyaan yang menjadi indikator bagaimana peran guru di Sekolah Menengah Kejuruan (SMK) Negeri 02 Tembilahan dalam menangani pelanggaran disiplin siswa. Akan tetapi di dalam tehnik wawancara yang penulis lakukan hanya dua orang guru saja mengingat terlalu banyaknya guru Waka kesiswaan dan Guru Bimbingan Konseling (BK). berikut item-item pertanyaan disertai dengan hasil wawancara penulis terhadap guru yang menjadi subjek penelitian yang dapat dilihat pada keterangan dibawah ini.

Wawancara pertama penulis lakukan pada hari senin, 2 Februari 2015 bertempat di kantor Majlis Guru, wawancara kepada Guru bimbingan konseling (BK) Yang bernama Bapak Triyono, adapun hasil wawancaranya adalah sebagai berikut:

\section{a. Teknik Inner Control.}

Bagaimana usaha Bapak menumbuhkan kepekaan dan penyadaran tata tertib kepada siswa di sekolah?

Usaha saya dalam menumbuhkan penyadaran tata tertib kepada siswa di sekolah dengan cara memberikan pemahaman secara berlahan-lahan kepada siswa mengenai betapa pentingnya kedisiplinan akan tata tertib itu bagi seorang pelajar, sehingga kesadaran mengenai kedisiplinan itu tumbuh dan berkembang dalam diri siswa dan diharapkan siswa dapat mengendalikan dirinya sendiri.

\section{b. Teknik External Control}

$\begin{array}{llr}\text { Bagaimana usaha } & \text { Bapak } \\ \text { memberikan bimbingan } & \text { dan } \\ \text { penyuluhan kepada } & \text { siswa } \\ \text { mengenai kedisiplin? } & \end{array}$
usaha saya memberikan bimbingan dan penyuluhan kepada siswa yakni dengan pengawasi siswa baik dilingkungan sekolah ataupun diluar lingkungan sekolah, apabila terdapat siswa yang melanggar norma yang tidak wajar saya akan langsung memanggil dan menanyakan langsung kepada siswa tersebut dan menjatuhkan hukuman.

\section{c. Teknik Cooperative Control}

Apakah Bapak dan siswa saling bekerja sama dalam pelanggaran tata tertib?

Ya, kami majelis guru memang saling bekerjasama dalam hal pelanggaran kedisiplinan tata tertib yang dibuat sekolah. apa siswa melihat temannya melanggar tata tertib maka siswa harus melaporkan kepada guru piket. akan tetapi banyak siswa tidak melakukan itu karena siswa takut atau lain sebagainya, hanya 
sebagian siswa saja yang berani melakukan laporan itu. ${ }^{30}$

Wawancara kedua penulis lakukan pada hari yang sama yakni hari Senin, 2 Februari 2015 bertempat di ruangan piket, wawancara kepada Guru waka kesiswaan Yang bernama Dwi Yusma Puspita, adapun hasil wawancaranya adalah sebagai berikut:

\section{a. Teknik Inner Control.}

Bagaimana usaha Bapak menumbuhkan kepekaan dan penyadaran tata tertib kepada siswa di sekolah?

Usaha saya dalam menumbuhkan penyadaran tata tertib kepada siswa di sekolah dengan cara memberikan arahan mengenai pentingnya kedisiplinan dan saya harapkan siswa dapat mematuhi tata tertib yang sekolah buat.

\section{b. Teknik External Control}

Bagaimana usaha Bapak memberikan bimbingan dan penyuluhan kepada siswa mengenai kedisiplin?

usaha saya memberikan bimbingan dan penyuluhan kepada siswa yakni dengan pengawasi gerak gerik siswa disekolah baik jam belajar di kelas maupun jam istirahat siswa, dan apabila terdapat siswa yang melanggar saya akan melaporkan keguru piket.

\section{c. Teknik Cooperative Control}

Apakah Bapak dan siswa saling bekerja sama dalam pelanggaran tata tertib?

Ya, kami majelis guru memang saling bekerjasama dalam hal pelanggaran kedisiplinan tata tertib yang dibuat sekolah, dan apabila salah seorang siswa melihat ada temannya yang melanggar harus wajib melaporankan nya. $^{31}$

${ }^{30}$ Wawancara, Bapak Triyono, Hari senin 2 Februari 2015.
Dari wawancara yang penulis lakukan di atas dapat penulis simpulkan bahwa usaha guru dalam menumbuhkan kesadaran disiplin siswa dengan secara perlahan-lahan serta memberikan pemahaman tentang penting kedisiplin bagi seorang siswa sehingga siswa dapat mengendalikan dirinya dengan baik, sedangkan usaha guru dalam memberikan bimbingan dan penyuluhan dengan cara pengawasi siswa baik di luar sekolah maupun di dalam sekolah apabila terdapat pelanggarn maka siswa tersebut di berikan sangsi atau hukuman, yang terakhir guru dan siswa harus bekerjasama dalam menegakkan kedisiplinan sekolah.

\section{Analisa Hasil Data Penelitian}

a. Analisa Hasil Observasi

Dari hasil observasi yang telah penulis lakukan pada 13 Responden mengenai peran guru dalam menangani pelanggaran disiplin di Sekolah Menengah Kejuruan (SMK) Negeri 02 Tembilahan Kota, dapat dilihat melalui penjabaran tabel rekapitulasi sebagai berikut.

\section{Tabel IV.32}

\section{Rekapitulasi Hasil Observasi Peran}

Guru Dalam Menangani Pelanggaran

Disiplin Siswa Di Sekolah Menengah Kejuruan (SMK) Negeri 02 Tembilahan Kota

\begin{tabular}{|c|c|c|c|c|c|}
\hline \multirow{3}{*}{$\mathrm{NC}$} & \multirow{3}{*}{$\begin{array}{l}\text { Aspek Yang di } \\
\text { Teliti }\end{array}$} & \multicolumn{4}{|c|}{ Option Jawaban } \\
\hline & & \multicolumn{2}{|c|}{ YA } & \multicolumn{2}{|c|}{ TIDAK } \\
\hline & & $\mathrm{F}$ & $(\%)$ & $\mathrm{F}$ & $(\%)$ \\
\hline \multirow[t]{3}{*}{1} & $\begin{array}{l}\text { Guru menindak } \\
\text { siswa yang } \\
\text { berambut tidak } \\
\text { rapi: }\end{array}$ & & & & \\
\hline & a. Panjang & 21 & 80,77 & 5 & 19,23 \\
\hline & b. Di cat & 23 & 88,47 & 3 & 11,53 \\
\hline
\end{tabular}

${ }^{31}$ Wawancara, Ibu Dwi Yusma Puspita, Hari senin 2 Februari 2015. 


\begin{tabular}{|c|c|c|c|c|c|}
\hline & c. Di garis & & 42,31 & 15 & 57,69 \\
\hline \multirow{3}{*}{2} & $\begin{array}{l}\text { Guru melarang } \\
\text { siswa mencat: }\end{array}$ & & & & \\
\hline & a. Kuku & 15 & 57,69 & 11 & 42,31 \\
\hline & $\begin{array}{l}\text { b. Berkuku } \\
\text { panjang }\end{array}$ & 17 & 65,38 & 9 & 34,62 \\
\hline \multirow{3}{*}{3} & $\begin{array}{l}\text { Guru melarang } \\
\text { siswa memakai } \\
\text { aksesoris yang } \\
\text { berlebihan: }\end{array}$ & & & & \\
\hline & $\begin{array}{l}\text { a. Siswa laki-laki } \\
\text { (kalung, cincin, } \\
\text { anting-anting) }\end{array}$ & 12 & 46,16 & 14 & 53,84 \\
\hline & $\begin{array}{l}\text { b. Siswa } \\
\text { perempuan (rok } \\
\text { mini/rok di atas } \\
\text { lutut) }\end{array}$ & 26 & 100 & 0 & 0 \\
\hline 4 & $\begin{array}{l}\text { Guru menindak } \\
\text { siswa yang } \\
\text { mengaktifkan } \\
\text { handphone pada } \\
\text { proses belajar } \\
\text { mengajar. }\end{array}$ & 16 & 61,53 & 10 & 38,47 \\
\hline 5 & $\begin{array}{l}\text { Guru menindak } \\
\text { siswa yang } \\
\text { datang terlambat } \\
\text { dalam mengikuti } \\
\text { proses belajar } \\
\text { mengajar. }\end{array}$ & 12 & 46,16 & 14 & 53,84 \\
\hline \multirow{5}{*}{6} & $\begin{array}{l}\text { Guru menindak } \\
\text { siswa yang } \\
\text { mengancam: }\end{array}$ & & & & \\
\hline & a. Guru & 22 & 84,61 & 4 & 15,39 \\
\hline & b. Teman & 22 & 84,61 & 4 & 15,39 \\
\hline & $\begin{array}{l}\text { c. Merusak } \\
\text { sarana }\end{array}$ & 15 & 57,69 & 11 & 42,31 \\
\hline & d. prasarana & 25 & 96,16 & 1 & 3,84 \\
\hline 7 & $\begin{array}{l}\text { Guru } \\
\text { menghukum } \\
\text { siswa merokok } \\
\text { di lingkungan } \\
\text { sekolah }\end{array}$ & 25 & 96,16 & 1 & 3,84 \\
\hline 8 & $\begin{array}{l}\text { Guru melarang } \\
\text { siswa } \\
\text { bertato(bertindik) } \\
\text { terutama siswa } \\
\text { laki-laki }\end{array}$ & 26 & 100 & 0 & 0 \\
\hline
\end{tabular}

${ }^{32}$ Amirul Hadi dan Hayono, Metodologi Penelitian Pendidikan, (Bandung: CV Pustaka Setia, 2005), hlm. 45.

\begin{tabular}{|c|l|c|c|c|c|}
\hline 9 & $\begin{array}{l}\text { Guru menindak } \\
\text { siswa yang } \\
\text { terlibat } \\
\text { perkelahian di } \\
\text { luar maupun di } \\
\text { dalam } \\
\text { lingkungan } \\
\text { sekolah. }\end{array}$ & 24 & 92,31 & 2 & 7,69 \\
\hline 10 & $\begin{array}{l}\text { Guru menindak } \\
\text { siswa yang } \\
\text { terlibat: }\end{array}$ & & & & \\
\hline a. Narkoba & 8 & 30,77 & 18 & 69,23 \\
\hline $\begin{array}{l}\text { b. Minuman } \\
\text { keras }\end{array}$ & 19 & 73,08 & 7 & 26,92 \\
\hline & JUMLAH & $\mathbf{3 3 9 7 2 , 4 3}$ & $\mathbf{1 2 9}$ & $\mathbf{2 7 , 5 7}$ \\
\hline
\end{tabular}

Dari tabel rekapitulasi hasil observasi keseluruhan di atas, dapat kita lihat bahwa jawaban "Ya" berjumlah 339, sedangkan jawaban "Tidak" berjumlah 129 dari 18 aspek yang diteliti mengenai peran guru dalam menangani pelanggaran disiplin siswa di Sekolah Menengah Kejuruan (SMK) Negeri 02 Tembilahan Kota. Adapun perhitungan nya dengan langkah-langkah sebagai berikut:

$$
\mathrm{P}=\frac{F}{N} \mathrm{X} 100 \%
$$

Untuk menentukan nilai $\mathrm{F}$ dengan cara memberikan bobot pada jawaban hasil observasi. Untuk jawaban "Ya" dengan bobot (1) sedangkan jawaban “Tidak" dengan bobot (0). ${ }^{32}$

Untuk menentukan $\mathrm{F}$ dengan cara:
a. Nilai Ya
: 339 X $1=339$
b. Nilai Tidak
: $129 \times 0=0$

Sedangkan untuk menentukan nilai $\mathrm{N}$ dengan cara sebagai berikut: $\mathrm{N}=$ item observasi X Jumlah Observasi $\mathrm{X}$ Responden X Skor tertinggi

$$
\begin{aligned}
& N=18 \times 1 \times 26 \times 1 \\
& N=468
\end{aligned}
$$


Untuk menentukan nilai

persentase, digunakan rumus:

$$
\begin{aligned}
\mathrm{P} & =\frac{F}{N} \mathrm{X} 100 \% \\
\mathrm{P} & =\frac{339^{\circ}}{468} X 100 \% \\
\mathbf{P} & =\mathbf{7 2 , 4 3 \%}
\end{aligned}
$$

Berdasarkan rekapitulasi hasil observasi di atas tentang "Peran Guru Dalam Menangani Kedisiplinan Siswa di Sekolah Menengah Kejuruan (Smk) Negeri 02 Tembilahan Kota" adalah "Baik" dengan persentase $\mathbf{7 2 , 4 3 \%}$ Guru telah melaksanakan indikator-indikator yang menyangkut tentang peran seorang guru disekolah.

\section{b. Analisa Hasil Wawancara}

Dari hasil wawancara yang penulis lakukan kepada guru waka kesiswaan dan guru bimbingan konseling (BK) Sekolah Menengah Kejuruan (SMK) Negeri 02 Tembilahan Kota tentang usaha guru dalam menangani pelanggaran kedisiplinan siswa dapat penulis simpulkan menumbuhkan kesadaran disiplin siswa dengan secara perlahan-lahan serta memberikan pemahaman tentang penting kedisiplin bagi seorang siswa sehingga siswa dapat mengendalikan dirinya dengan baik, memberikan bimbingan dan penyuluhan dengan cara pengawasi siswa baik di luar sekolah maupun di dalam sekolah apabila terdapat pelanggarn maka siswa tersebut di berikan sangsi atau hukuman, yang terakhir guru dan siswa harus bekerjasama dalam menegakkan kedisiplinan sekolah.

\section{KESIMPULAN}

Dari observasi dan wawancara yang penulis lakukan tentang peran guru dalam menangani kedisiplinan siswa di Sekolah Menengah Kejuruan (SMK) Negeri 02 Tembilahan Kota, dapat penulis simpulkan "BAIK" dengan persentase $72,43 \%$ interval berkisar antara $61 \%-80 \%$.

Adapun usaha guru dalam menangani pelanggaran kedisiplinan siswa di Sekolah Menengah Kejuruan (SMK) Negeri 02 Tembilahan Kota yaitu menumbuhkan kesadaran disiplin siswa dengan secara perlahan-lahan serta memberikan pemahaman tentang penting kedisiplin bagi seorang siswa sehingga siswa dapat mengendalikan dirinya dengan baik,memberikan bimbingan dan penyuluhan dengan cara pengawasi siswa baik di luar sekolah maupun di dalam sekolah apabila terdapat pelanggarn maka siswa tersebut diberikan sangsi atau hukuman, yang terakhir guru dan siswa harus bekerjasama dalam menegakkan kedisiplinan sekolah.

\section{REFERENSI}

Abdul Majid, (2006), Prencanaan pembelajaran, Jakarta: Rosda Karya

Abin Syamsudin Makmun, (2012), Psikologi Kependidikan, Bandung: PT Rosdakarya

Abudin Nata, (1996), Filsafat Pendidikan Islam, (Bandung: Logos

Ahmad Rohani, (2004), Pengelolaan Pengajaran, Jakarta: Rineka Cipta

Amirul Hadi dan Hayono, (2005), Metodologi Penelitian Pendidikan, Bandung: CV Pustaka Setia, 2005

Aprilia Kumala dan F. Arundaya, (2010), Kamus Bahasa Indonesia, Surabaya: Ikhtiar

Awaluddin Tjala, 2004, 10 Kesalahan Orang Tua dan Guru dalam 
Mendidik dan solusinya, Bogor: Aan-Najah Press

Departemen Agama RI, (2005), Al-qur'an dan terjemahannya, Bandung: CV. Penerbit J-Art

Didi Supriadie dan Deni Darmawan, (2012), Komunikasi Pembelajaran, Bandung: PT Remaja Rosdakarya

Eka Prihatin, 2011, Manajemen Peserta Didik, (Bandung: Alfabeta

Hasbullah, (2008), Dasar-Dasar Ilmu Pendidikan, Jakarta: Raja Grafindo Persada

Imam Wahyudi, 2012, Mengejar Profesionalisme Guru, Jakarta: Prestasi Pustaka

Mahfan, (2005), Kamus lengkap Bahasa Indonesia Sastra Indonesia, Jakarta: Sandra Jaya

Muhammad Nurdin, (2010), Kiat Menjadi Guru Profesional, Jogyakarta: ArRuzz Media Group

E. Mulyasa, (2013), Manajemen Pendidikan Karakter, (Jakarta: Bumi Aksara

Novan Ardy Wiyani, (2013), Manajemen KelasTeori dan Aplikasi Untuk Menciftakan Kelas Yang Kondusif, Jogjakarta: Ar-Ruzz Media

Oemar Hamalik, (2011), Proses Belajar Mengajar, Jakarta: Bumi Aksara

Oemar Hamalik, (2011), Psikologi Belajar Mengajar, Jakarta: Sinar Baru Algensindo

Pupuh Fathurrohman dan M. Sobry Suntikno, (2010), Strategi Belajar Mengajar, Bandung: PT. Rafika Aditama

Riduwan, (2011), Belajar Mudah Penelitian Guru-Karyawan Peneliti Pemula, Bandung: Alfabeta, 2011

Sudarwan Danim dan Khairil, (2010), Proofesi Kependidikan, Bandung: Alfabeta

Sugiono, (2010), Penelitian Pendidikan, Bandung: Alfabeta
Suharsimi Arikunto, (2006), Prosedur penelitian suatu pendekatan praktik, Jakarta: PT. Rineka Cipta

Suharsimi, A. (1992). Prosedur penelitian: Suatu pendekatan praktik. Jakarta: Rineka Cipta

Waka Bidang Kesiswaan Sekolah Menengah Kejuruan Negeri 02 Tembilahan Kota, (2013), Tata Tertib Siswa, Tembilahan 